\title{
Encoding Transfer Events in Surinamese Javanese
}

\author{
Sophie Villerius \\ Radboud University Nijmegen Centre for Language Studies, The Netherlands \\ sophievillerius@gmail.com
}

\author{
Francesca Moro \\ Leiden University, The Netherlands \\ francesca.romana7@yahoo.it
}

\author{
Marian Klamer \\ Leiden University, The Netherlands \\ m.a.f.klamer@hum.leidenuniv.nl
}

\begin{abstract}
This paper examines the influence of language contact and multilingualism on the encoding of transfer events in the heritage variety of Javanese spoken in Suriname. Alongside Javanese, this community also speaks Sranantongo and Dutch, of which Sranantongo had the longest contact history with Javanese. It is shown that this long period of contact had a structural influence on the expression of transfer events in Surinamese Javanese: Surinamese speakers use double object constructions and twopredicate constructions more frequently than homeland Javanese speakers, a change which we argue to be due to contact with Sranantongo. In addition, Surinamese Javanese speakers overgeneralize one of the two applicative suffixes found in transfer constructions, a phenomenon that results from simplification processes.
\end{abstract}

\section{Keywords}

Javanese - Sranantongo - structural transfer - ditransitives - cross-linguistic influence - double object constructions 


\section{Introduction}

The domains where languages show variable syntax are often vulnerable in language contact situations, and can undergo structural transfer. Here, we study the interaction between language contact and variability in Surinamese Javanese, an Austronesian language spoken in a highly dynamic trilingual contact situation in Suriname, alongside the official language Dutch and the lingua franca Sranantongo. We investigate ditransitive constructions which express events where an Agent-participant "transfers" a Theme-like object to a Recipient-like participant. The two non-Agent arguments involved in such events may be ordered in various ways, and receive different encodings (a variation commonly referred to in English as the 'dative alternation/shift'). The variability or alternation of transfer constructions is likely to be the locus of cross-linguistic influence as proposed by the Alternation Hypothesis (Jansen et al., 1981) and the Vulnerability Hypothesis (de Prada-Pérez, 2015). When there is variability between two or more grammatical constructions, bilingual speakers tend to use the construction that is shared by both languages (Jansen et al., 1981; Silva-Corvalán, 1994; Boumans, 2006; Onar Valk, 2015; Kootstra and Şahin, 2015; Moro and Klamer, 2015; Moro, 2016). The Vulnerability Hypothesis assumes a categorical-variable continuum, such that variable phenomena are prone to change while categorical phenomena are not (de Prada Pérez, 2015). The rationale behind this is that variability is difficult for multilingual (heritage) speakers to acquire, and consequently it becomes the target of possible dominant language influence. For instance, Turkish has two types of subordinate clauses, finite ones and non-finite ones. Turkish-Dutch bilinguals living in the Netherlands have been found to overgeneralize the option that is also found in Dutch, namely the finite subordinate clause (Onar Valk and Backus, 2013).

Variable grammatical domains of language can undergo frequency change due to language contact, so that the frequency distributions of the constructions in the heritage language become similar to those of the dominant language. This kind of change is referred to as "frequential copying" by Johanson (2002: 292): the frequential properties of a construction or pattern in the dominant language are transferred into the heritage language. In this way, an existing pattern in the heritage language which is marked can become unmarked under the influence of the dominant language, because of an increase in its frequency.

From the perspective of language contact, Javanese presents an interesting case as the expression of transfer events shows variability in two dimensions: not only are the clausal constructions themselves variable, but there is 
also variability in the applicative suffixes on the verbs that are part of these constructions. Both variable dimensions are expected to be vulnerable, and to undergo linguistic change. The first phenomenon, the clausal construction used, is expected to be affected more by language external factors, such as cross-linguistic influence from Sranantongo and Dutch. The second phenomenon, the variable use of applicative affixes, is expected to be affected by language-internal developments reinforced by contact.

In other languages (e.g. Ambon Malay and Papiamento, see below), the domain of ditransitive or transfer events has been shown to be vulnerable to contact, since it often shows variability in the order and grammatical marking of the arguments. The term 'transfer events' is used here to refer to a specific subset of ditransitive verbs: those that encode 'give' or 'show' events. In the expression of a transfer event, there can be variation in the ordering and encoding of the recipient-like argument $(\mathrm{R})$ and the transferred object or theme argument (T). Cross-linguistically, the most frequently discussed structures to express ditransitive events are those involved in the so-called 'dative alternation/shift' (Bresnan et al., 2007; Colleman, 2009; Broekhuis et al., 2015). In this alternation, there are two main constructions. The first is the prepositional object construction (PO), in which $\mathrm{R}$ is marked with a prepositional phrase (John gave a book to Mary). The second construction is the double object construction, owing its name to the fact that both objects ( $\mathrm{R}$ and $\mathrm{T})$ appear unmarked, usually in a fixed order following the verb (John gave Mary a book).

The frequency and distribution of these constructions is vulnerable to language contact, mostly affecting the preference of speakers for one construction or the other. In a study of the PO/DO alternation among Ambon Malay-Dutch bilinguals in the Netherlands, Moro and Klamer (2015) observed an increase in the frequency of DO constructions as a result of cross-linguistic influence from Dutch. A similar increase in frequency under the influence of Dutch was found in Papiamento-Dutch bilinguals; but in this case, it was the PO construction that was used more frequently (Kootstra and Şahin, 2015).

As we will demonstrate, Indonesian Javanese has a clear preference for encoding transfer events by means of a PO construction. Surinamese Javanese, however, is in contact with, on the one hand, Sranantongo, a language that strongly prefers DO constructions, and on the other hand, Dutch, a language with a preference for PO constructions in certain contexts. Given the different context in which Surinamese Javanese is spoken, the questions addressed in this paper are thus: To what extent has the encoding of transfer events in Surinamese Javanese been restructured as compared to the Indonesian Javanese? And which role, if any, did contact with Sranantongo and Dutch play in the restructuring? 
The current study shows that the encoding of transfer events in Surinamese Javanese has been restructured to the extent that Surinamese Javanese speaker use more DO constructions compared to Indonesian Javanese speakers. This result indicates that variability in syntax indeed makes a construction vulnerable to change in a contact situation. Our study also shows that Surinamese Javanese has been mostly influenced by Sranantongo in its choice of preferred construction for transfer events. We know that the contact with Sranantongo has been taking place for a longer period of time than the contact with Dutch (see section 2), which indicates that duration of contact is an important factor in grammatical restructuring.

The structure of this paper is as follows. In section 2, we present a general introduction into constructions of transfer events in language contact situations. Then we will discuss the position of Javanese as a contact language in section 2. In section 3, we turn to a description of ditransitive transfer constructions in the three languages of the contact situation: Javanese, Sranantongo, and Dutch. In sections 4.1 and 4.2 we outline the methodology of the present study, and in section 4.3 we present and discuss the results. In section 5 we formulate our conclusions.

\section{Background on the Speech Communities}

Surinamese Javanese (ISO code jav) is one of the heritage languages of the Republic of Suriname, a sovereign state on the northeastern Atlantic coast of South America. Surinamese Javanese, an Austronesian language, has been spoken in Suriname for about one century. It is a 'heritage' language in the sense that it is a minority language to which speakers have been exposed from early childhood, usually through their parents or grandparents. When the young heritage language speakers enter school, they usually switch to the dominant language (cf. Van Deusen-Scholl, 2003: 222). Because of this interrupted acquisition, proficiency in and usage of the heritage language varies greatly among speakers, and it offers a unique opportunity to investigate contact effects (see Villerius 2017, 2018a and 2018b for additional studies on contact effects in Surinamese Javanese).

Suriname, as a former colony of The Netherlands, hosts a large variety of ethnic groups, brought together throughout the Dutch colonial rule. Surinamese Javanese is spoken by the descendants of the Javanese contract laborers who were brought to Suriname to work on the plantations after the abolition of slavery in 1863. Between 1890 and 1939, a total of 32,956 contract laborers were transported to Suriname by the Dutch colonial regime from the island of Java, Indonesia (Hoefte, 1987:3). 
Since there is much dialectal variation in Javanese as spoken in Java (Robson, 1992: 4; Robson and Wibisono, 2002: 8; Ewing, 2005: 5), it is important to pinpoint the exact origin of these laborers, so that the similarities and differences between Indonesian Javanese and Surinamese Javanese can be properly assessed. Vruggink (2001) calculates that as much as $70 \%$ of the Surinamese Javanese originated from Central Java. The database of Javanese immigration (Nationaal Archief, 1999) gives the 105 most frequent places of origin of Javanese immigrants (including those with place of origin 'unknown'), accounting for 15,709 immigrants (of 32,956 in total; Derveld, 1982: 25). An analysis of these records (as carried out by the first author) confirms Vrugginks numbers: $68 \%$ of the contract laborers originated from Central Java, 19\% from East Java, $4 \%$ from West Java and $9 \%$ were of unknown origin. Since the vast majority of Javanese speakers in Suriname originated from Central Java, we consider this variety as our baseline homeland variety, and we interviewed speakers of Central Javanese as our control group. For the purpose of this paper we use the term 'homeland speakers' to refer to this group.

One of the most striking characteristics of the community of Javanese in Suriname is that virtually all of them are also fluent in Sranantongo and Dutch (which are often their functionally dominant languages), resulting in a situation where three languages are in contact with each other. There has been no systematic research yet on the variety of Dutch and Sranantongo spoken by the Surinamese Javanese, but in this paper we will assume that it is grammatically equal to the variety of other Surinamese speakers.

Sranantongo is an English-lexifier creole spoken in Suriname, and is a member of the Surinam subgroup of the Atlantic English-based creole languages (Adamson and Smith, 1994: 219). It developed as a means of communication on the plantations from as early as the mid-seventeenth century. Nowadays, it is spoken by virtually the whole population of Suriname as a first or second language, and frequently used as a means of communication between different ethnic groups. Bilingualism of the Javanese in Sranantongo probably started with the arrival of the Javanese contract laborers on the plantations at the end of the $19^{\text {th }}$ century. The Javanese laborers had to gain some knowledge of Sranantongo in order to communicate with other non-Javanese speaking workers on the plantations. At that time, Dutch was probably not yet used in everyday contexts. Only after World War II did Dutch enter the picture, when education became increasingly important, which in Suriname took place in Dutch (see Figure 1). This, we assume, has led to differences in the influence that either Sranantongo or Dutch had as source languages for structural changes in Surinamese Javanese, because the contact with Sranantongo has been taking place for a longer period of time. 
JAVANESE IN SURINAME

189o's

1950 's

2010's

Javanese in contact with Sranantongo

Javanese in contact with Dutch

FIGURE 1 Schematic representation of the timeline of Javanese language contact in Suriname

The differential influence of Sranantongo and Dutch on Surinamese Javanese is also seen when we compare the speech of different generations of speakers. A conversation recorded by the first author where an 86 year old speaker interacts with two younger speakers aged 50 and below showed that the older speaker used Sranantongo more often as a source language for code-mixing, phonologically integrating these loans more heavily into Javanese, while the younger speakers code-switched to Dutch more often, and employed more Dutch borrowings (Villerius, 2017).

The participants in this study describe the societal role of Surinamese Javanese as the cultural, 'in-group' language, spoken within the home and the Javanese community. Dutch, the official language of Suriname, is used in schools, in official communication by the government, in most of the media and in working environments. The Surinamese Javanese participants often described Sranantongo as a somewhat 'informal' language, spoken mostly with peers in informal contexts. However, it must be noted that this description certainly does not apply to the situation in Suriname as a whole, since Sranantongo is also widely used in political discourse and has an extensive written tradition (Adamson and Smith, 1994: 220; Adamson and Van Rossem, 1994: 75). The participant's limited description of the societal role of Sranantongo may be related to the fact that it is considered to have lower prestige in comparison to Dutch (e.g. Charry, Koefoed and Muysken, 1983: 65; Yakpo, 2015).

At this point, it is important to emphasize that during the century in which the Javanese have been living in Suriname, the language of the homeland, Indonesian Javanese, also underwent changes of its own. After Indonesia's independence, Indonesian became the national language of Indonesia, used in education and media; and all languages spoken in Indonesia, including Javanese, have been influenced by it. However, Indonesian and Javanese are genealogically closely related and typologically very similar in their phonology, morphology, argument encoding, constituent order and TMA-marking (e.g. Sato, 2008: 259). Since the area under investigation here mainly concerns 
argument encoding and constituent order, we assume that due to the similarity between Indonesian and Javanese in these domains the Indonesian influence on Javanese in the expression of transfer events is virtually absent. If any influence did take place, we believe that it would rather strengthen the typological patterns already present in Javanese, as a type of structural reinforcement of pre-existing structures through contact (Aikhenvald and Dixon, 2006: 32 ).

It is important to distinguish the variety of Dutch spoken in Suriname from Dutch as spoken in The Netherlands and Belgium. Surinamese Dutch is an ethnolect of Dutch (De Kleine, 2007; Muysken, 2013; Muysken, 2017), and was first mentioned at the beginning of the $20^{\text {th }}$ century by Van Ginniken (1913; cited in Muysken, 2013). Its basis is European Dutch from The Netherlands, with strong substrate influences from Sranantongo (Muysken, 2017: 289), and possibly influences from second language acquisition processes (Muysken, 2017: 291). Most studies on Surinamese Dutch focus on the domains where deviations from European Dutch are found: its lexicon and semantics. Studies investigating possible syntactic differences are yet scarce, but Muysken (2017) provides a list of distinctive syntactic features of Surinamese Dutch. ${ }^{1}$

Surinamese Javanese has thus been in contact with both Sranantongo and Dutch, but there are important differences in the socio-historical contexts of both contact settings. As for the duration of contact, we can distinguish between two main 'layers': whereas Sranantongo has been in contact with Javanese from the very beginning of immigration up until now, the influence of Dutch began later, after World War II (see Figure 1).

\section{Transfer Verb Constructions in Javanese, Sranantongo and Dutch}

This section presents a description of the structures used to encode transfer events in the three languages that are in contact in Suriname: Indonesian Javanese (section 3.1), Sranantongo (section 3.2) and Dutch (section 3.3). We will see that each language allows a variety of structures, and that some of these occur across the three languages, while others are unique for an individual language. We discuss the similarities and differences between the three languages, and frequency effects.

1 These include the frequent non-realization of function words er 'there' and expletive het 'it', overuse of demonstrative deictics as determiners, overgeneralization of common gender, and verb-medial (rather than verb-final) word order in subordinate clauses. 


\subsection{Indonesian Javanese}

The description below is based primarily on the possibilities and preferences of Indonesian Javanese. However, all of the constructions occur in both heritage Surinamese Javanese and homeland Indonesian Javanese. The examples presented below come from our own corpus of Indonesian and Surinamese Javanese unless stated otherwise. In Indonesian Javanese, different encodings of transfer events not only show variation in syntactic constructions but also show differences in the morphological shape of the transfer verb.

3.1.1 Double Object (DO) and Prepositional Object (PO) Constructions Indonesian Javanese uses both the DO and PO construction to encode transfer events (see Ogloblin, 2005: 602 for Standard Javanese; Arps et al., 2000: 435 for Central-Javanese; Hemmings, 2013: 173 for East-Javanese; Conners, 2008: 74 for Tengger Javanese). These constructions are characterized by having a main verb with a nasal prefix ${ }^{2}$ which derives the so-called 'actor voice' (AV) (in contrast to the 'undergoer voice' (UV), see section 3.1.3). The AV-prefix on the verb indicates that the actor (or agent) argument of the verb is the subject of the clause, while the non-agent arguments are objects. The objects of AV-verbs of transfer are expressed in either the DO or the PO construction. In a DO construction, both $\mathrm{R}$ and $\mathrm{T}$ appear as bare, unmarked, nominal constituents, following the verb, as illustrated in example (1). ${ }^{3}$

(1) Verb- $i$ DO recipient-theme

$\begin{array}{llll} & & \mathbf{R} & \mathbf{T} \\ \text { Ibu } & \text { nge-kèk-i } & {[a k u]} & {[\text { dhuwit }]} \\ \text { mother } & \text { AV-give-APPL } & \text { 1SG } & \text { money }\end{array}$

'Mother gives me money' (Arps et al., 2000: 435)

In (1), the objects in the DO construction appear in the order $\mathrm{R}$ (ecipient)$\mathrm{T}$ (heme). However, the order T-R is also possible with AV-verbs of transfer as in (2):

(2) verb-i DO theme-recipient

\begin{tabular}{|c|c|c|c|c|c|}
\hline $\begin{array}{l}\text { Wong } \\
\text { person }\end{array}$ & $\begin{array}{l}\text { lanang-é } \\
\text { male-DEF }\end{array}$ & $\begin{array}{l}n \text {-duduh-i } \\
\text { AV-show-APPL }\end{array}$ & $\begin{array}{l}\text { T } \\
{[\text { klambi] }} \\
\text { cloth }\end{array}$ & $\begin{array}{l}\mathbf{R} \\
\text { [tyah } \\
\text { child }\end{array}$ & $\begin{array}{l}\text { lanang-é }] \\
\text { male-DEF }\end{array}$ \\
\hline "The ma & $\begin{array}{l}\text { shows (a p } \\
50826-\mathrm{Ma}\end{array}$ & $\begin{array}{l}\text { ce of) clothing t } \\
\text {-clips) }\end{array}$ & the boy.' & & \\
\hline
\end{tabular}

\footnotetext{
2 The nasal prefix ng-[y] assimilates with the place feature of the following segment and is realised as ng-[n], n-, m-, or ny- [nj].

3 Orthographical conventions: è $=[\varepsilon] ;$ é $=[\mathrm{e}] ; \mathrm{ty}=[\mathrm{t}]], \mathrm{j}=[\mathrm{d} z], \mathrm{dh}=[\mathrm{d}], \mathrm{th}=[\mathrm{t}]$.
} 
In a PO construction, bare $\mathrm{T}$ follows the verb and $\mathrm{R}$ is the complement of the preposition nèng, as illustrated in (3).

(3) verb-ké PO theme-recipient

$\begin{array}{lllll}\text { Ibu } & \text { nge-kèk-ké } & \text { T } & \text { Prep } & \text { R } \\ \text { mother } & \text { AV-give-APPL }] & \text { nèng } & {[a k u]} \\ \text { 'Mother gives money to me.' (Arps et al., } & \text { 2000: } & \text { 435) }\end{array}$

Note that the Javanese DO-PO alternation goes hand in hand with using different applicative/causative suffixes on the verb: in (1) the suffix $-i$ licenses postverbal R, in (3), the suffix - (a)ké licenses postverbal T. Thus, Indonesian Javanese has a DO-PO alternation that is reminiscent of the 'dative alternation' in English or Dutch, but the Javanese alternation is typologically different in at least two respects: (i) in Javanese, the order in which objects occur in the DO construction is also variable, and (ii) the morphology of the main verb plays a role in determining which object ( $\mathrm{R}$ or $\mathrm{T}$ ) is directly adjacent to the verb.

The Javanese applicative suffixes $-i$ and $-k e$ are associated with a range of mostly valency-changing functions, of which an overview is given below in Table 1.

TABLE 1 Overview of the functions of Javanese applicative suffixes $-i$ and $-(a) k e ́$, with illustrations

(cf. Robson, 1992; Vruggink, 2001; Ogloblin, 2005; Ewing, 2005; Hemmings, 2013)

Suffix $-i$

Suffix -(a)ké

- Causative: ng-resik-i (AV-clean-APPL) 'clean up' - Causative: ng-lebok-aké

- Introduce recipient, goal or location argument: (AV-enter-APPL) 'to put in' ng-irim-i (AV-send-APPL) 'send to X'

- Introduce a benefactive:

- Express pluractionality, repetition or intensity of the verbal action: $n g$-usung-i (AV-carrytukok-aké (buy-APPL) 'to buy for X' APPL) 'carry with many people'

- 'To provide X with, to apply to X': ng-lenga-ni (AV-oil-APPL) 'put X in oil'

- 'To act as': $m$-bocah-i (AV-child-APPL) 'to act childishly'

- Express 'goal-orientedness': krungu 'hear X' vs. ng-rungokaké (AV-hear-APPL) 'listen to $\mathrm{X}^{\prime}$

- Indicate "a more specific relation with the object" (Robson, 1992: 57): ng-golèk (AV-seek) 'to seek' vs. ng-golèk-i (AV-seek-APPL) 'to seek something in particular'

- 'To consider X as [base]': m-bener-aké (AV-right-APPL) 'to consider $\mathrm{X}$ as right' 
From Table 1 it is clear that $-i$ and -(a)ké have some overlapping functions (for example, the causative function, and the function to introduce a goal), but also that $-i$ has a wider range of meaning associated with it than - $(a) k e ́$. Concerning the form of the suffix $(a) k e ́$ : this is variable across the Javanese dialects, and it occurs as -ké, and -aké, but also as -na and -né. The suffix -na is the East-Javanese variant of -ké (Robson, 1992; Arps et al., 2000), and the form -né may be considered a merger of this East-Javanese -na and Central-Javanese -ké. This is relevant, since the present study assumes Surinamese Javanese was based on the Central-Javanese dialect, so that we do not expect the suffixes -na and -né to surface in our data.

When Javanese applicative suffixes are used with transfer verbs, the most important semantic-syntactic difference between them is as follows. As a suffix to a transfer verb, $-i$ licenses an $\mathrm{R}$ object that is semantically a recipient, location or goal, and appears in a DO construction. $\mathrm{R}$ can occur directly adjacent to the verb (in the construction "verb- $i \mathrm{R}$ T"), as shown in example $(4),{ }^{4}$ or following $\mathrm{T}$ (in the construction "verb-i T R"), as in example (2) above.

(4) verb-i DO recipient-theme

$\begin{array}{llllll}\text { Wong lanang } & \text { nge-wènèh-i } & \mathbf{R} & & \mathrm{T} \\ \text { persong } & \text { wadon }] & {[\text { dhus }]} \\ \text { 'A male gives a woman a box.' (JVN-20140522-SoRo-clips) }\end{array}$

The suffix - ké, by contrast, introduces a benefactive argument or a notion of increased 'goal-orientedness' to the verb, and usually appears in a PO construction, where the PO containing $\mathrm{R}$ follows $\mathrm{T}$ (in the construction "verb-ké $\mathrm{T}$ $[\text { Prep } R]_{\text {PO }}$ ), see example (5).

(5) verb-ké PO theme-recipient
Iki ana cah lanang-é nge-kèk-ké $\quad \begin{array}{lll}\mathbf{T} & \mathbf{R} \\ \text { [tas-é }] & {[\text { karo kanca-né }]}\end{array}$
this EXIST child male-DEF AV-give-APPL bag-DEF with friend-DEF 'Here is a boy giving the bag to his friend.' (JAV-20150529-FaAl-clips)

The data in the current study indicate that the association between having a verb with an $-i$ suffix and DO constructions on the one hand, and having a

\footnotetext{
4 Cross-linguistically, this is the most frequently used order in DO constructions (Haspelmath, 2013).
} 
verb with a -ké suffix and PO constructions on the other, is subject to change among heritage speakers of Javanese (see section 4.3.2).

Indonesian Javanese thus shows a PO-DO alternation, as well as variable orders within the DO construction itself. Existing literature does not provide information on preferential frequencies of these constructions among native speakers. For this reason we conducted a pre-study to examine patterns of frequency. We analyzed data from eight Javanese speakers from Central and EastJava in Indonesia, who were asked to describe six video stimuli (the same as those that were used in the exploration of the heritage data, see section 4.2.2). The results show a clear preference for $\mathrm{PO}(78.8 \%)$, whereas no DO at all was found in the data. ${ }^{5}$ As for the use of morphology in the PO construction, in the majority of cases $(61.5 \%)$ a verb with the suffix -ké introduces the T, while in the remaining $38.5 \%$ of the utterances the $\mathrm{T}$ is introduced by suffix $-i$. Thus, in our elicited dataset there is a preference for $\mathrm{PO}$ constructions with verbs suffixed with -ké.

In sum, according to the literature, $\mathrm{PO}$ and $\mathrm{DO}$ are both possible in Indonesian Javanese. In elicitation contexts, however, speakers prefer to encode transfer events by means of a PO construction, with suffix -ké introducing the theme argument.

\subsubsection{Argument Omission Constructions}

In descriptions of transfer events in Indonesian Javanese, one of the non-actor arguments may be left unexpressed, even when they are clearly visible in the stimulus. We refer to these constructions as 'argument omission constructions'. In example (6), the T of ngèki 'give' is left unexpressed; in (7), it is the R of nduduhké 'show'.

(6) Theme omission

Ènèk wong lanang karo wong wédok ngadeg. Wong lanang-é ng-èk-i [wong wédok] EXIST person male with person female standing person male-DEF AV-give-APPL person female 'There is a man with a woman standing. The man gives (something to) the woman.'

(JVN-20140523-FlWa-clips)

5 The remaining $21 \%$ consisted of argument omission constructions and two-predicate constructions (see section 3.1.2 and 3.1.4). 
(7) Recipient omission

\begin{tabular}{lcc} 
& \multicolumn{1}{c}{ T } \\
Wong & $n$-duduh-ké & [jas $]$ \\
person & AV-show-APPL & jacket \\
'A person shows a jacket.' (JAV-20160407-Wiwi-clips)
\end{tabular}

\subsubsection{Undergoer Voice}

In Indonesian Javanese, the verb can have two voices: actor voice (AV, with the nasal prefix discussed in section 3.1.1) or undergoer voice (UV). UV is expressed with the verbal prefix $d i$-. This prefix licenses an undergoer argument to be the subject of the clause, and to occur in pre-verbal subject position. In UVtransfer verb constructions, the subject undergoer can be either the R, as in (8), or the $\mathrm{T}$, as in (9).

(8) Recipient undergoer as subject of verb derived by di-

R $\quad$ T

Ènèk tyah tyilik karo wong lanang. [Tyah tyilik-é] di-kèk-i [klambi] EXIST child little with person male child little-DEF Uv-give-APPL cloth 'There is a child with a man. The little child is given (a piece of) clothing.' (JVN-201406o5-MaDo-clips)

(9) Theme undergoer as subject of verb derived by di$\mathrm{T}$

[Tas-é] di-kèk-ké wong lanang-é menèh bag-DEF UV-give-APPL person male-DEF again

'The bag is given to the man again.' (JVN-20150826-MaSo-clips)

Different suffixes are used on the verb 'give' in (8) (di-kèk-i) and (9) (di-kèk-ké). Thus, the question may be asked whether there is an association between choice of suffix and selecting either $\mathrm{R}$ or $\mathrm{T}$ as clausal subject. We believe the answer is negative. As the data discussed in section 4.3.2 will show, there is variation in the usage of these suffixes among native speakers, and no conclusive evidence for either association is found in the literature (e.g. Arps et al., 200o). ${ }^{6}$ In this paper we will therefore focus on the differences and similarities

6 Arps et al. (2000: $364-368)$ state that an UV-verb with a recipient undergoer can take either suffix $-i$ or $-k e ́$, so the selection of an R subject does not trigger the choice for a certain suffix. However, in the UV construction the usage of suffix $-i$ is more marginal and only possible with a limited set of verbs, such as 'to lend' (Arps et al., 2000: 435). 
between the heritage and homeland group with regards to these suffixes, which will be discussed in section 4.3.2.

\subsubsection{Two-predicate Constructions}

In Indonesian Javanese, the expression of a transfer event may also be split between two predicates, where one predicate introduces $\mathrm{T}$ and the other $\mathrm{R}$. More specifically, as can be seen in (10), the first predicate involves an activity where an active subject handles $\mathrm{T}$, while the second predicate involves a transfer event where $T$ is the (implied) subject of the verb in undergoer voice, and $R$ is the object.

(10) Two-predicate construction

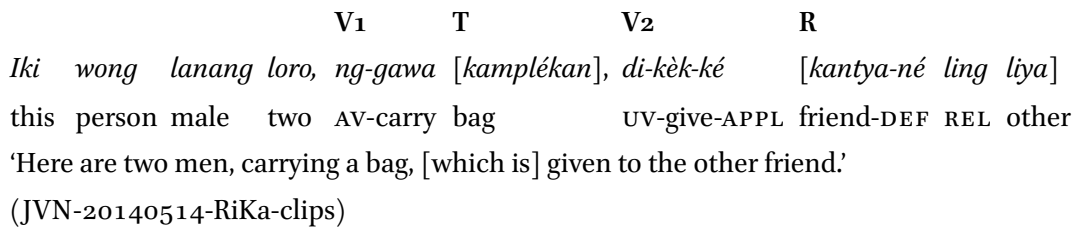

Constructions involving two predicates to express a complex event are sometimes referred to as 'serial verb constructions' (cf. Crowley, 2002: 8-19), a term that will be encountered later in the discussion on Sranantongo constructions. However, we use the broader notion 'two-predicate construction' to refer to constructions in our data that contain two predicates along the cline from 'serial verbs' to 'asyndetic parataxis' to 'conjoined clauses', where the clauses are not separated by an audible pause and the shared subject is expressed only once (see section 3.2.2).

\subsection{Sranantongo}

This section provides an overview of the types of constructions used to encode transfer events in Sranantongo. Illustrations are taken from the literature and from the dataset described in section 4.2.1 (the latter are marked with 'SRA11').

\subsubsection{DO and PO constructions}

In Sranantongo, the DO construction illustrated in (11) is the most common construction to express transfer events (Voorhoeve, 1964; Bruyn et al., 1999; Yakpo, 2017). Sranantongo also has the option to use a PO construction, where

7 Note on orthography: examples from the literature are given in the original source orthography, but with standardized glosses. Examples from the dataset are given in standard Sranantongo orthography. 
$\mathrm{R}$ follows $\mathrm{T}$ and is embedded in a prepositional phrase, as shown in (12) with preposition $n a$.

(11)

$\begin{array}{llllll} & & & \mathbf{R} & \mathbf{T} & \\ M & e & g i & {[\text { hen }]} & {[\text { wan }} & \text { sani }] \\ \text { 1SG } & \text { PRES } & \text { give } & \text { 3SG } & \text { ART.INDF } & \text { thing }\end{array}$

'I give him a thing.' (Voorhoeve, 1964: 22)

(12)

\begin{tabular}{|c|c|c|c|c|c|}
\hline & & & $\mathrm{T}$ & Prep & $\mathbf{R}$ \\
\hline Joe & ben & $g i$ & [datti] & $n a$ & {$[\mathrm{mi}]$} \\
\hline $2 S G$ & PAST & give & that & LOC & $1 \mathrm{SG}$ \\
\hline
\end{tabular}

The PO construction with preposition $n a$ is the one that has traditionally been described in the literature. However, a recent paper by Yakpo (2017) suggests that there is another construction in Sranantongo which has been reanalyzed as a PO: a construction with two predicates, where the first verb is a verb of transfer, such as langa 'hand over', and the second verb is gi 'give'. See example (13) below. In these cases, which have traditionally been analyzed as serial verb constructions, it appears that synchronically, gi should be analyzed as a preposition, since the transfer event is already encoded in the V1. Yakpo argues that this reanalysis took place under the influence of Dutch, which has a strong preference for $\mathrm{PO}$ constructions.

\begin{tabular}{|c|c|c|c|c|c|c|c|c|}
\hline & & & $V_{1}$ & $\mathrm{~T}$ & & $V_{2}$ & $\mathbf{R}$ & \\
\hline$A$ & man & $e$ & langa & [wan & tas] & $g i$ & {$[a$} & trawan] \\
\hline ART.DEF & man & IPFV & hand.over & ART.INDF & bag & give & ART.DEF & other \\
\hline
\end{tabular}

In terms of frequency, while both DO and PO constructions are possible, the literature suggests that DO constructions are preferred (e.g. Winford and Plag, 2013). Voorhoeve's (1964) description of Sranantongo syntax contains a text with 21 occurrences of ditransitive constructions with the verb $g i$ 'give', and all of these are DO construction where $\mathrm{R}$ and $\mathrm{T}$ directly follow the verb. In the corpus provided by Arends (1989), we find 17 DO constructions versus two PO constructions with the verb gi 'give'. In Yakpo (2017) ditransitive constructions in a corpus of spoken Sranantongo are analysed. ${ }^{8}$ Counting 141 occurrences of

8 Part of this corpus overlaps with the data described in section 4.2.1 of this paper. 
10 different ditransitive verbs, Yakpo shows that $64 \%$ of these (90/141) occur in DO constructions (Yakpo 2017: 72, Table 6). The remaining 36\% utterances contain 'serial verb constructions', which he later goes on to classify as PO constructions, by arguing that $g i$ as a $\mathrm{V}_{2}$ has been reanalyzed as a preposition under the influence of Dutch. Further evidence for the preference for DO in Sranantongo is provided by our own analysis of a written source, Sye! Arki Tori!, a collection of stories by Aleks de Drie (1985), written in Sranantongo. We did a search for ditransitive constructions in the first three chapters of this source, and found that out of the 28 constructions with the verb gi 'to give', 25 were DO constructions. The other three were cases of constructions with multiple predicates, with $g i$ as $\mathrm{V}_{2}$, which as we will see later can synchronically be classified as PO's, following Yakpo (2017). The only other ditransitive verb that was frequent enough (i.e. more than one occurrence) was the verb of communication taygi 'to tell.' This verb occurred seven times in a ditransitive construction, all of which were DO constructions.

\subsubsection{Two-predicate Constructions}

Another option to express transfer events in Sranantongo is through a twopredicate construction where the first predicate is usually an object handling verb like teki 'take', tyari 'carry' or hori 'to hold', and has T as its object, while the second predicate is a verb of transfer, such as gi 'give' or sori 'show' and has $\mathrm{R}$ as its object. Examples are (14) and (15). These cases are arguably different from the once described above as PO constructions, since here the V2 gi still receives a literal meaning of expressing the transfer event (because the first verb is a light verb with no literal meaning).

$\begin{array}{lllllll} & \text { V1 } & \text { T } & & \text { V2 } & \mathbf{R} & \\ \text { Kofi } & \text { tyari } & {[a} & \text { nyan }] & \text { gi } & {[\text { en }} & \text { mama }] \\ \text { Kofi } & \text { carry } & \text { DEF } & \text { food } & \text { give } & 3 \text { SG } & \text { mother }\end{array}$

'Kofi brought his mother the food.' (Sebba, 1987: 113)

\begin{tabular}{|c|c|c|c|c|c|c|c|}
\hline & & & V1 & $\mathrm{T}$ & V2 & $\mathbf{R}$ & \\
\hline$A$ & man & hori & wan & buku & sori & {$[a$} & trawan] \\
\hline ART.DEF & man & hold & ART.INDF & book & show & ART.DEF & other \\
\hline
\end{tabular}

Constructions like these, where the verbs share at least one argument and are not connected with any conjunction, are often referred to as 'serial verb constructions' in the literature on Sranantongo (e.g. Sebba, 1987). A type very similar to the constructions in (14) and (15) are cases such as (16) below, where 
the verb types are the same but the two clauses are less tightly joined because of the pronoun $a$ which is repeated, and the pause after buku.
(16) $A$
man teki wan
buku, a
sori a
trawan
ART.DEF man take ART.INDF book ART.DEF show ART.DEF other
'The man takes a book, he shows to the other man.' (SRA11MAL-KE)

As we have shown above, Javanese also has an option to encode transfer events by means of a construction with multiple predicates; the two-predicate construction (section 3.1.4). In this construction, the two verbs do not necessarily share a subject and the clauses can be connected by means of a conjunction. The essential similarity between the serial verb constructions in (14) and (15), the construction in (16) and two-predicate constructions in Javanese is that the information is segmented into two predicates or clauses. Both sub-components of the transfer-event are expressed by verbs. The first verb means 'hold', 'take' or 'carry', while the second verb is a verb of transfer, 'give' or 'show'. For the sake of comparison, in this paper we will group all of these constructions together under the label 'two-predicate construction'.

As for the relative frequency of the two-predicate constructions expressing transfer events, Bruyn et al. (1999:340) state that "the actual distribution of the DOC [=DO], the PDC [=PO], and the SDC [=two-predicate construction] in modern Sranantongo usage" is "not quite clear". Most references suggest a preference for DO constructions (Voorhoeve, 1964; Arends, 1989; Winford and Plag, 2013; Bruyn et al., 1999 for older Sranantongo). From this we conclude that the main construction in Sranantongo to encode transfer events is the DO construction. The other constructions are less frequent nowadays. However, we assume that the two-predicate construction with gi as a $\mathrm{V}_{2}$ was still more frequent when the Javanese contract laborers arrived in Suriname a century ago, since the reanalysis of $g i$ as a preposition seems to be a recent development under the influence of Dutch.

\subsection{Dutch}

This section provides an overview of the types of constructions used to encode transfer events in Dutch, where we aim to focus as much as possible on what is known about Surinamese Dutch. Illustrations are taken from the data sets on Surinamese Dutch and Netherlands Dutch, described in section 4.2.1.

\subsubsection{DO and PO Constructions}

Like Javanese and Sranantongo, Dutch also has both a DO and PO construction to express transfer events. In the DO construction, as in (17), the order of 
arguments following the verb is always R-T. In the PO construction in (18), $\mathrm{R}$ follows $\mathrm{T}$ and is introduced with the preposition aan 'to'.

\begin{tabular}{|c|c|c|c|c|c|c|c|c|}
\hline & & & & $\mathbf{R}$ & & & $\mathrm{T}$ & \\
\hline$D e$ & ene & man & geeft & {$[d e$} & andere & $\operatorname{man}]$ & [een & rugzak] \\
\hline RT.DEF & one & man & give.3SG & ART.DEF & other & man & ART.INDF & backpack \\
\hline
\end{tabular}

'The one man gives the other man a backpack.' (Moro and Klamer, 2015: 272)

\begin{tabular}{llllllll} 
& \multicolumn{9}{c}{$\mathrm{T}$} & \multicolumn{5}{c}{ Prep } & $\mathbf{R}$ \\
Een & man & geeft & {$[$ een } & paar schoenen $]$ & aan & {$[$ een } & vrouw $]$ \\
ART.INDF & man & give.3SG & ART.INDF & pair shoes & LOC & ART.INDF & woman \\
'A man gives a pair of shoes to a woman.' (NED11sha2-ke) & & &
\end{tabular}

For lack of data on Surinamese Dutch, we assume that the same factors governing the choice between DO and PO in Netherlands Dutch also holds for Surinamese Dutch. Factors that govern the choice between DO and PO in Dutch include the length of the phrases expressing the arguments, their animacy and the information packaging especially of the $\mathrm{R}$ argument (Moro and Klamer, 2015: 272-273). As for the factor of phrase length: the longer the $\mathrm{R}$ phrase (e.g. a full nominal phrase), the more it tends to be positioned at the end of the clause. Shorter R's (e.g. pronouns) will therefore have a higher probability to figure in a DO construction where they precede T. As for animacy, an $\mathrm{R}$ argument is canonically animate and is more likely to figure in a PO construction when it is inanimate, since a DO construction with an inanimate $\mathrm{R}$ is infelicitous. ${ }^{9}$ Finally, since the animate (human) $\mathrm{R}$ is usually given and more topical than the T, a PO construction is more likely to be used when R is not topical but rather new information. ${ }^{10}$

Dutch transfer constructions in elicitation show a stronger preference for PO (82.6\%) over DO (4.3\%) (Moro and Klamer, 2015: 279). This finding is in line with other studies which found a strong preference for $\mathrm{PO}$ constructions in decontextualized experiments (Colleman and Bernolet, 2012: 96, 104), and a preference for DO constructions in corpora (Colleman, 2009; Colleman and Bernolet, 2012:94). In other words, the preference for either a DO or a PO construction in Dutch is context-dependent. The elicitation context we are discussing here is similar to those of Moro and Klamer (2015), so for the purpose of this study, we take PO as the preferred strategy for Dutch transfer constructions.

$9 \quad$ For example: ?Ik geef de bibliotheek het boek 'I give the library the book'.

10 For example: Ik geef het boek aan hem, niet aan jou 'I give the book to him, not to you' rather than ?Ik geef hem het boek, niet jou 'I give him the book, not you'. 


\subsubsection{Argument Omission}

Dutch also allows for the omission of an argument in a ditransitive transfer construction. Most often this is the $\mathrm{R}$, since this is canonically the more topical argument, as discussed above. An illustration is (19).

\begin{tabular}{llllll}
\multicolumn{1}{c}{ Een } & man & laat & {$[$ een } & boek $]$ & zien \\
ART.INDF & man & let.3SG & ART.INDF & book & see.INF
\end{tabular}

'A man shows a book.' (Moro and Klamer, 2015: 272)

\subsubsection{Object Fronting}

Another possibility in Dutch is to move one of the arguments to the initial position of the main clause, preceding the verb, as illustrated with the T argument 'the bag in his right hand' in (20).

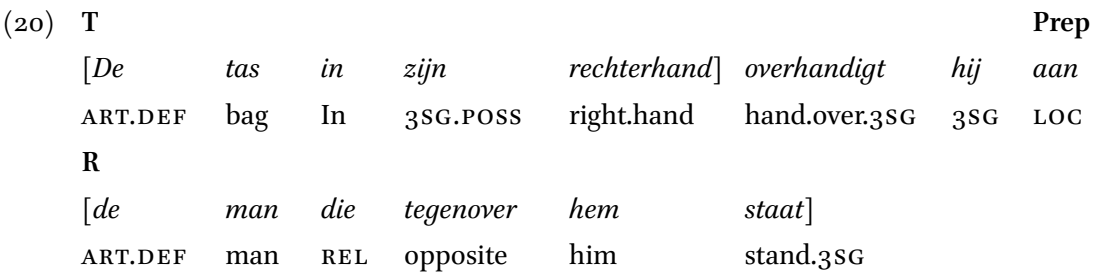

'The bag in his right hand he hands over to the man who stands in front of him.'

(Moro and Klamer, 2015: 274)

The object-fronting construction in Dutch and the undergoer voice construction in Javanese (section 3.1.3) are similar in that both have $\mathrm{R}$ or $\mathrm{T}$ as the first constituent of the clause. The crucial difference is that in Dutch objectfronting, the initial constituent is the grammatical object of the same verb that is used in unfronted constructions, while in Javanese undergoer voice constructions, it is the grammatical subject of an undergoer voice verb. The two constructions are thus distinguished on syntactic grounds.

\subsection{Summary}

Javanese, Sranantongo and Dutch all employ DO as well as PO constructions to express transfer events. Javanese has a preference for PO (section 3.1.1), Sranantongo prefers DO (section 3.2.1). In Dutch, the choice is conditioned by a combination of formal, pragmatic and contextual factors, but in the particular experimental context that is analysed here, Dutch prefers PO (section 3.3.1).

In addition, Javanese and Dutch share the possibility of omitting an argument, while Javanese and Sranantongo share the possibility of using a 
TABLE 2 Overview of the constructions available in the three languages: $+=$ possible, $++=$ preferred

$\begin{array}{lll}\text { Construction Javanese } & \text { Sranantongo }\end{array}$

$\begin{array}{llll}\text { PO construction } & ++ & + & ++ \\ \text { DO construction } & + & ++ & + \\ \begin{array}{l}\text { Argument omission } \\ \text { Undergoer voice }\end{array} & + & & + \\ \begin{array}{l}\text { Object fronting } \\ \text { Two-predicate }\end{array} & & & + \\ \text { construction } & + & + & \end{array}$

two-predicate construction. Table 2 presents a summary of possible and preferred constructions per language.

\subsection{Research Questions}

We have seen that Javanese allows a number of different constructions to encode transfer events, namely constructions with PO, DO (recipient-theme), DO (theme-recipient), two-predicate, argument omission and undergoer voice (see Table 2 and section 3.1). Furthermore, a Javanese transfer verb ('give' or 'show') can host two possible applicative suffixes, -ké and -i. As Surinamese Javanese has been separated from the homeland variety since the $1890^{\prime}$ 's, it is likely to have grown distinct from homeland Indonesian Javanese (section 2). The central question addressed here is thus whether the encoding of transfer events in Surinamese Javanese has undergone restructuring when compared to the homeland Javanese variety.

To answer this question, we focus on two variables: (i) the frequency of various transfer constructions; and (ii) the use of the applicative suffixes -ké and -i. We focus on these specific areas as these are the domains where variation between the two varieties is observed. Variable structures like these are known to be vulnerable in language contact settings (Jansen et al., 1981; Boumans, 2006; Silva-Corvalán, 1994, 2008; Onar Valk and Backus, 2013; Moro, 2016).

Regarding the frequency of various transfer constructions, the 'Alternation Hypothesis' predicts that if the heritage language offers an alternation between 
two constructions, heritage speakers will tend to copy the frequency of the construction existing in his or her dominant language (Jansen et al., 1981; Moro, 2016: 32). Thus, we investigate the frequencies of various transfer constructions because we expect this to be a domain of cross-linguistic influence. When speakers have various constructions available to express the same event, influence from (an)other language(s) can affect their preferences, in such a way that bilingual speakers will more often select the construction that is shared by both of the languages they speak.

Some of the transfer constructions that occur in Surinamese Javanese are shared with both Sranantongo and Dutch (see Table 2, section 3.4). In Sranantongo, the DO construction (recipient-theme) is most preferred (section 3.2.1). In Dutch, the PO construction is the preferred construction in elicited data (section 3.3.1). Influence from the preferred patterns in either Sranantongo (DO) or Dutch (PO) would thus result in overgeneralizing either DO or PO in Surinamese Javanese.

Here we expect that Surinamese Javanese converges with Sranantongo more than with Dutch, because Surinamese Javanese and Sranantongo have been in contact for over one hundred years, while the period of contact with Dutch was only fifty years (see section 2 ). We thus predict a change in the $\mathrm{DO} / \mathrm{PO}$ alternation, such that Surinamese Javanese speakers will use DO (recipienttheme) constructions with a higher frequency than Javanese homeland speakers, due to influence of Sranantongo. We also predict an increase in the frequency of two-predicate constructions in Surinamese Javanese, again due to the influence of Sranantongo, where two-predicate constructions were still very frequent in the $19^{\text {th }}$ and $20^{\text {th }}$ century, since the reanalysis as a PO construction is a later development.

Note, however, that the frequency of DO, PO and two-predicate constructions in a heritage language can already shift significantly during a relatively short period of 50-60 years of bilingualism, as Moro and Klamer (2015) have shown for heritage Malay in the Netherlands. Thus, it is a matter of empirical evidence to determine whether Suriname Javanese is more influenced by Sranantongo than by Dutch. For this reason, we also include Dutch data in our comparative analysis.

The second variable phenomenon we investigate here is the use of the two applicative suffixes -ké and $-i$ in Surinamese Javanese transfer constructions. These suffixes have distinct but overlapping functions, and their use varies even in monolinguals (see section 3.1.1). Structures that are variable in the monolingual grammar are more vulnerable to change in multilingual speakers. This finding has been formalized in the Vulnerability Hypothesis (de Prada 
Pérez, 2015). The rationale behind this hypothesis is that for multilingual speakers variability in structure is more difficult to both acquire and retain. Consequently, variable structures become the target of incomplete acquisition, attrition or cross-linguistic influence. The non-transparent form-function mapping of the -ké and $-i$ suffixes is likely to pose a challenge to bilingual heritage speakers of Surinamese Javanese. In addition, bound morphology is arguably one of the most fragile areas of heritage languages: morphemes in heritage languages may be either lost or overgeneralized. Morphological loss in heritage languages has been reported for heritage speakers of Arabic, Korean, Russian and Spanish in the U.S.A. (see Benmamoun et al., 2013); morphological overgeneralization has been observed in heritage speakers of Russian (Polinsky, 2008).

These earlier heritage language studies lead us to expect changes in the use of $-k e$ and $-i$ among Surinamese Javanese heritage speakers. We predict that one or both are lost, or their function is overgeneralized. In addition, we expect that if one of the two suffixes is to be overgeneralized, this will be $-i$, because $-i$ has a wider range of functions than -ké in Javanese (see Table 1 in section 3.1.1). Morphological change in speakers can often be seen as the result of languageinternal processes of change, rather than being the direct result of crosslinguistic transfer (Thomason and Kaufman, 1991: 115; Benmamoun et al., 2010 and references therein). In the case at hand, the wide range of functions covered by ké- and $-i$ makes these suffixes susceptible to the (language-internal) mechanism of simplification. This simplification process is likely to be reinforced by language contact, as heritage speakers of Javanese in Suriname are dominant in Sranantongo and Dutch, two languages which lack suffixes with similar functions that could have influenced the use of -ké or - $i$ in Surinamese Javanese. Thus, when we predict that $-i$ will be overgeneralized, we do not claim that this is due to direct cross-linguistic influence from Sranantongo or Dutch. Rather, we consider the different usage of the applicative affixes in Surinamese Javanese as compared to homeland Javanese to be the result of a languageinternal process of morphological simplification triggered by contact.

In short, this paper investigates possible restructuring in the expression of Surinamese Javanese transfer events by focusing on two variable phenomena: (i) the frequency of various transfer constructions and (ii) the use of the applicative suffixes - $k e$ and $-i$. The first phenomenon is expected to be vulnerable to language external factors, such as cross-linguistic influence from Sranantongo and Dutch - with Sranantongo expected to have more influence than Dutch. The second phenomenon is expected to be vulnerable to languageinternal factors reinforced by contact. 


\subsection{Methodology \\ 4.2.1 Participants}

Because of the multilingual situation in Suriname, our research involved five different groups of participants, as laid out in Table 3.

The speakers of Surinamese Javanese originate from both urban (Paramaribo) and rural areas (Lelydorp, Tamanredjo, Domburg, La Vigilantia) in Suriname. The homeland Javanese speakers are all from Central Java, Indonesia. The Sranantongo and the Surinamese Dutch data consist of two different data sets, all of which were collected in Suriname. These data were collected by Yakpo and Hanenberg in 2011, and by the first author in 2017 (more on this in section 4.2.2). All the speakers of Surinamese Dutch were also proficient in Sranantongo, and three of them were also proficient in Surinamese Javanese. There is some overlap between the different groups; all of the speakers of Surinamese Dutch and Sranantongo from the 2017 dataset (two Surinamese Dutch and three Sranantongo) also participated in the data elicitation for Surinamese Javanese as informants. Two speakers that participated in the elicitation for Surinamese Dutch in 2012 also took part in the Sranantongo elicitation. The main data set for Dutch is from Surinamese Dutch speakers, as this is the variety of

TABLE 3 Overview of participants in all groups

\begin{tabular}{lrrrl}
\hline Group & N & Male & Female & Mean age \\
\hline Surinamese Javanese heritage speakers $^{11}$ & 36 & 11 & 25 & 44.83 \\
Central Javanese homeland speakers $^{12}$ & 21 & 10 & 11 & $46.5^{2}$ \\
Sranantongo speakers $^{13}$ & 12 & 7 & 5 & 47.6 \\
Surinamese Dutch speakers $^{14}$ & 7 & 3 & 4 & 34.85 \\
Netherlands Dutch speakers $^{15}$ & 10 & 4 & 6 & 40 \\
\end{tabular}

\footnotetext{
11 Data collected by Sophie Villerius, 2014, 2015 and 2017.

12 Data collected by Sophie Villerius, 2016.

13 Data collected by Yakpo and Hanenberg, 2011 (9 speakers) and Sophie Villerius, 2017 (3 speakers).

14 Data collected by Yakpo and Hanenberg, 2011 (5 speakers) and Sophie Villerius, 2017 (2 speakers).

15 Data collected by Rowan Soolsma and analysed by Francesca Moro (Moro and Klamer, 2015; Moro, 2016).
} 
Dutch that the Surinamese Javanese speakers are in contact with. Additionally, we used data from Dutch as spoken in the Netherlands. These data were collected using the same stimuli and the same procedure as was used for the two Javanese groups. None of the speakers of Netherlands Dutch had any knowledge of Sranantongo or Javanese.

\subsubsection{Stimuli and Procedure}

The heritage and homeland Javanese, as well as the Netherlands Dutch participants were asked to give an oral description of six video clips that depicted an event where one person gives or shows an object (a pair of shoes, a bag, a book or a jacket) to another person. These six video clips were taken from a larger set of 65 video clips that were previously used in the heritage language research of Moro (2016) and Irizarri van Suchtelen (2016). ${ }^{16}$ The six clips were shown in random order, mixed with distractor stimuli. By using these clips, two of the factors that have an influence on the choice on DO and PO, animacy and discourse accessibility (see section 3.3.1), were kept constant. In the clips, A and R were always animate (humans), while $\mathrm{T}$ was always inanimate (an object). As none of the clips had any discourse context and all videos showed different situations and involved different participants, none of the participants could be seen as previously 'given' and all of them had equal discourse accessibility. For these reasons, it was less likely that participants would use short terms such as pronouns to refer to the $\mathrm{R}$ or $\mathrm{T}$.

The Sranantongo and Surinamese Dutch data from 2011 were collected as part of the Traces of Contact project (ERC Project \#230310). ${ }^{17}$ This project involved different authors who employed a slightly different procedure. The participants were presented with only three video clips depicting transfer events (not six) and the clips were shown to the participants in sequence (as part of a larger set), unlike our own data where the stimuli were presented in random order mixed with distractor-stimuli. The next section discusses the results.

We will complete this section with an explanation of which responses were included and excluded. Only those responses were included which featured a

16 The source of these six video clip is F. Jäger, E. Norcliffe, K. Housel, J. Bohnemeyer and colleagues, University of Rochester, NY, USA, online URL https://hlplab.wordpress.com/ 2008/07/26/follow-up-experiments-on-sentence-production-in-yucatec/ [Last accessed 14 January 2016].

17 The ERC-project Traces of Contact (2009-2013) aimed to establish criteria by which results from language contact studies can be used to strengthen the field of historical linguistics, online URL http://www.ru.nl/linc/projects/erc-traces-contact/ [Last accessed 10 May 2018]. 
verb expressing physical transfer similar to 'to give' (kèk 'to give', wèh/wènèh 'to give (to)', tawa 'to offer', ulung 'to give/hand over', serah 'to hand over') or visual transfer (duduh 'to show'). Responses which used non-transfer types of verbs, such as gawa 'carry', tyekel 'take', ijol 'trade/change' were excluded. We also excluded reduplicated verbs which express a reciprocal activity more than a transfer-event; examples include oper-operan 'to exchange' and ijol-ijolan 'to exchange/trade with each other' as in (21). Example (21) is SurinameseJavanese (source code JVN), examples (22)-(23) are homeland Javanese (source code JAV).

$\begin{array}{llll}\text { (21) Ana } & \text { wong lanang karo wong wédok, apa wong lanang loro, } \\ \text { EXIST } & \text { person man } & \text { with person female or person male two } \\ \text { ijol-ijol-an } & \text { karo sak-wijining tas } & & \\ \text { RDP trade-AN } & \text { with one-certain bag } & \end{array}$

'There is a man and a woman, or two men, exchanging a certain bag.'

(JVN-20140514-WaKa-clips)

Other excluded constructions were those in which a speaker self-repaired, as illustrated in (22), or where speakers mixed elements from different constructions, resulting in a hybrid construction that could not be classified as one of the types described earlier. An example is given in (23).

$\begin{array}{llllll}\text { (22) Ana } & \text { wong lanang karo } & \text { wong wedok, Wong lanang-é kuwi } \\ \text { EXIST } & \text { person male with } & \text { person female person male-DEF that } \\ n \text {-yerah-ké } & \text { sak ker-, n-delok-ké } & \text { sak ker-, kerdus ning } & \text { wedok-é } \\ \text { AV-hand.over-APPL } & \text { one box- } & \text { AV-look-APPL one box- box LOC } & \text { female-DEF }\end{array}$

'There is a man and a woman, the man gives a bo-, shows a box to the woman.'

(JAV-20160402-Rati-clips)

\begin{tabular}{llllll} 
(23) & M-enèh-na & sepatu & ambèk, & ki sepatu-mu, & \multicolumn{2}{c}{ sepatu-ku, } & \\
AV-give-APPL & shoe & with & this shoe-2SG.Poss & \multicolumn{2}{c}{ shoe-1sG.Poss } \\
sepatu-mu & di-ganti & & apa di-, & $n g$-anggo iki & waé \\
shoe-2SG.POSS & AV-replace & or UV & AV-wear this & just
\end{tabular}

'He gives the shoe to..., this is your shoe, my shoe. Your shoe is replaced or is.., he just wears it' (JAV-20160406-Muji-clips)

Table 4 presents an overview of the number of valid and excluded responses in each group. In the heritage group of Surinamese Javanese speakers, 33 responses were excluded: 27 responses contained no verb of physical or visual 
TABLE 4 Overview of valid and excluded responses in all groups

\begin{tabular}{lllr}
\hline Group & N of speakers & Responses & \\
\hline Surinamese Javanese heritage speakers & \multirow{2}{*}{36} & Valid & 183 \\
& & Excluded & 33 \\
Central Javanese homeland speakers & 21 & Valid & 102 \\
Sranantongo speakers & & Excluded & 24 \\
& 12 & Valid & 41 \\
Surinamese Dutch speakers & & Excluded & 4 \\
& 7 & Valid & 22 \\
Netherlands Dutch speakers & & Excluded & 5 \\
& 10 & Valid & 46 \\
& & Excluded & 14 \\
\hline
\end{tabular}

transfer, five responses were classified as hybrid, and one as self-repair. In the homeland group of Javanese speakers, two of the original 23 speakers were excluded because they used too many hybrid or self-repair strategies (more than four out of six responses). From the remaining responses, a further 24 were excluded: 22 had no verb of physical or visual transfer, one was a hybrid construction and one was self-repair. As for the control groups: for Sranantongo and Surinamese Dutch we excluded responses where no verb of visual or physical transfer was used; resulting in four exclusions in Sranantongo and five in Surinamese Dutch. For Netherlands Dutch we adopted the exclusions proposed by the authors (see Moro and Klamer, 2015).

\subsection{Results and Discussion}

In this section, we first compare the frequency of the various construction types in the five speaker groups and point out relevant differences (4.3.1). Most importantly, it is shown that the Surinamese speakers prefer DO and twopredicate constructions over PO constructions. Then we will look at the use of bound morphology on the predicate in the heritage and homeland Javanese groups (4.3.2). Finally, we will discuss and explain these results, and relate them to our initial research questions and hypotheses (4.3.3).

\subsubsection{Frequencies of Transfer Constructions}

The frequencies of the different transfer constructions in the five groups are summarized in Table 5 and discussed below. 
TABLE 5 Overview of types and frequencies of constructions used in all groups

\begin{tabular}{llllll}
\hline $\begin{array}{l}\text { Construction } \\
\text { type }\end{array}$ & $\begin{array}{l}\text { Surinamese } \\
\text { Javanese } \\
\text { heritage }\end{array}$ & $\begin{array}{l}\text { Central } \\
\text { Javanese } \\
\text { homeland }\end{array}$ & Sranantongo & $\begin{array}{l}\text { Surinamese } \\
\text { Dutch }\end{array}$ & $\begin{array}{l}\text { Netherlands } \\
\text { Dutch }\end{array}$ \\
\hline PO & $24(13.1 \%)$ & $36(35.3 \%)$ & $13(31.7 \%)$ & $18(81.2 \%)$ & $38(82.6 \%)$ \\
DO & $73(39.9 \%)$ & $5(4.9 \%)$ & $23(56.1 \%)^{18}$ & $4(18.2 \%)$ & $2(4.3 \%)$ \\
Argument & $25(13.7 \%)$ & $50(49.0 \%)$ & & & $4(8.7 \%)$ \\
omission & & & & & \\
UV & $22(12.0 \%)$ & $4(3.9 \%)$ & & & $2(4.3 \%)$ \\
Object fronting & $1(0.5 \%)^{19}$ & & & & \\
Two-predicate & $38(20.8 \%)$ & $7(6.9 \%)$ & $5(12.2 \%)$ & & \\
Total & 183 & 102 & 41 & 22 & \\
\hline
\end{tabular}

We used a two-tailed independent samples $t$-test to compare heritage Surinamese Javanese and homeland Javanese scores on the different constructions. ${ }^{20}$ Concerning the $\mathrm{DO} / \mathrm{PO}$ alternation, the results show that the frequency of $\mathrm{PO}$ is significantly lower in the heritage group than in the homeland group: $t(283)=7.175, p<0.001$. Conversely, the frequency of DO is significantly higher in the heritage group compared to the homeland group $(t(283)=-10.202$, $p<0.001)$. Argument omission constructions have a very high incidence in the homeland group $(49 \%)$ while they are much less common in the heritage group $(13.7 \%)(t(283)=10.634, p<0.001)$. On the other hand, undergoer voice constructions are much more frequent in the heritage group $(12.0 \%)$ than in the homeland group $(3.9 \%)(t(283)=-3.286, p=0.001)$. Finally, two-predicate constructions are used significantly more frequently in the heritage group than in the homeland group $(t(283)=-5.171, p<0.001)$.

18 Constructions such as $A$ boi langa gi wan tas trawan 'Lit. the boy hand.over give a bag other.one' were also included under DO constructions, since the T and R directly follow the verb unmarked. There were two such examples in the dataset. One reviewer commented that in these cases, langa gi could indeed be analysed as a compound verb.

19 This construction was similar to the undergoer voice construction, with one of the arguments in first position, while the verb is in the actor voice. Because of the low relative frequency, we will not discuss this construction further.

20 We used the two-tailed independent samples $t$-test because we wanted to be neutral with respect to the direction of change and because the two-tailed $t$-test is more conservative than the one-tailed $t$-test. 
Comparing the control groups, we see that Sranantongo has a strong preference for DO (56.1\%), followed by PO constructions (31.7\%) and two-predicate constructions (12.2\%). Of the PO constructions, 11 are of the type described above as having developed from a serial verb construction, with $g i$ as the preposition. The prepositions in the other two cases are general locative preposition $n a$ and fu 'for'. The Surinamese Dutch and Netherlands Dutch groups behave similarly: both have a higher preference for PO constructions (81.2\% for Surinamese and $82.6 \%$ for Netherlands), with DO being more marginal. The DO construction is relatively more frequent in the Surinamese Dutch group ( $18.2 \%$ versus $4.3 \%$ respectively), which could be explained by the fact that in the Netherlands group, there are some other constructions (argument omission and object fronting), while these are absent in the Surinamese group. This could be explained by differences in elicitation procedure. Within the Surinamese group, for most of the participants all stimuli were presented in sequence rather than in random order mixed with distractor stimuli (see section 4.2.2). When speakers then start using one construction, they will be more likely to re-use it for all consecutive stimuli, since it is still active in their mind, thus leading to less variation in the responses.

Regarding the DO construction, it was observed (see section 3.1.1) that Javanese allows the recipient and theme to occur in two different orders: R-T and T-R. The data are summarized in Table 6 and discussed below.

The heritage Surinamese Javanese group has a preference for R-T order (twice as frequent), while in the homeland Central Javanese group, the most frequent order is T-R. This difference is significant $(t(76)=3.006, p=0.04)$. As we have seen, R-T is the canonical argument order in Sranantongo as well as Dutch (see section 3.2 and 3.3).

To sum up, heritage Surinamese Javanese speakers use DO and twopredicate constructions more frequently than homeland Central Javanese speakers, who, in turn, prefer PO. Within the DO construction, heritage Surinamese Javanese also diverge from homeland speakers in showing a significant preference for the recipient-theme order which is both Sranantongo and Dutch-aligned.

TABLE 6 Overview of different orders in Javanese DO constructions

Construction Surinamese Javanese heritage Central Javanese homeland

$\begin{array}{lll}\text { DO recipient-theme } & 50(68.5 \%) & 1(20 \%) \\ \text { DO theme-recipient } & 23(31.5 \%) & 4(80 \%) \\ \text { Total DO } & 73 & 5\end{array}$




\subsubsection{Frequencies of Morphemes - ké and $-i$ in Transfer Constructions}

This section discusses the frequency of the applicative suffixes -ké and $-i$ in the different transfer constructions in the heritage and homeland Javanese groups. We first present data from the three actor voice constructions; namely PO, DO and argument omission. Recall that -ké selects the theme argument, and is, therefore, typically linked to a PO construction where the recipient is part of an adjunct phrase; while $-i$ selects the recipient argument and is thus expected to occur in a DO construction (see section 3.1.1).

As presented in Table 7 , in PO constructions, homeland speakers behave as expected and have a slight preference (21 out of 36 ) for -ké, while heritage speakers almost exclusively use $-i$, which is unexpected.

In DO constructions, shown in Table 8, both heritage and homeland speakers almost exclusively use $-i$, as was expected in DO constructions. Note however that because of the small number of observations, we cannot draw major generalizations about suffix use in the homeland group.

In argument omission constructions, shown in Table 9, where the recipient is omitted and the predicate is followed by only the theme, the heritage group prefers verbs with $-i$ while the homeland group shows a slight preference for suffixing verbs with -ké. Thus, according to the homeland Javanese grammar (see section 3.1.1) the homeland speakers again behave as expected, while the behaviour of the heritage group is slightly deviant. Both groups show only one case of theme omission, where the predicate is followed by the recipient only. In this construction, the verb is suffixed with $-i$ in the heritage group and with $-k e ́$ in the homeland group.

The data presented in Table 7 , Table 8 and Table 9 show a similar trend: a preference for $-i$ among heritage Javanese speakers. For the heritage group, in the overwhelming majority of cases the verb takes the suffix $-i$, regardless of whether it is part of a DO or PO construction, or being followed by a theme or a recipient. There is only one case (in a recipient omission construction, Table 9) where the verb takes the suffix -ké. When we look at the homeland data, we see that the connection of $-k e$ to PO and $-i$ to DO that was mentioned above, is a tendency but not an absolute rule: there are many cases where a

TABLE 7 Overview of suffixes on PO constructions in heritage and homeland Javanese

\section{PO construction Surinamese Javanese heritage Central Javanese homeland}

\begin{tabular}{lll}
\hline Suffix $-i$ & $22(91.7 \%)$ & $15(41.7 \%)$ \\
Suffix $-k e ́$ & $2(8.3 \%)$ & $21(58.3 \%)$ \\
Total & 24 & 36
\end{tabular}


TABLE 8 Overview of suffixes on DO constructions in heritage and homeland Javanese

DO construction Surinamese Javanese heritage Central Javanese homeland

\begin{tabular}{lll}
\hline Suffix $-i$ & $71(97 \cdot 3 \%)$ & $5(100 \%)$ \\
Suffix $-k e ́$ & $1(1.4 \%)$ & \\
No suffix & $1(1.4 \%)$ & 5 \\
Total & 73 & 5
\end{tabular}

TABLE 9 Overview of suffixes on argument omission constructions in heritage and homeland Javanese

Argument omission Surinamese Javanese heritage Central Javanese homeland

\begin{tabular}{lcllc}
\hline & Suffix $-i$ & Suffix $-k e ́$ & Suffix $-i$ & Suffix $-k e ́$ \\
Recipient omission & 22 & 1 & 21 & 26 \\
Theme omission & 2 & & & 1 \\
Total & 24 & 1 & 21 & 27 \\
\hline
\end{tabular}

TABLE 10 Overview of suffixes appearing on undergoer voice verbs in heritage and homeland Javanese

\begin{tabular}{lllll} 
UV constructions & \multicolumn{3}{c}{ Surinamese Javanese heritage } & Central Javanese homeland \\
\cline { 2 - 5 } & Suffix $-i$ & Suffix $-k e ́$ & Suffix $-i$ & Suffix $-k e ́$ \\
& & & 4 & \\
Recipient undergoer & 15 & 5 & & \\
$\begin{array}{l}\text { Theme undergoer } \\
\text { Total }\end{array}$ & 2 & 5 & 4 & \\
\hline
\end{tabular}

verb with $-i$ occurs in a DO construction, but also many cases where it occurs in a PO construction (see Table 7). However, -ké is almost exclusively attested in a PO construction; there is only one case of it occurring in a DO construction.

In the undergoer voice construction, we also notice a difference in the use of the applicative suffixes between heritage and homeland Javanese speakers. The data are summarized in Table 10 and discussed below. 
As we have seen in section 3.1.3, there is variability in the use of suffixes $-i$ or -ké in undergoer voice constructions. In our heritage group, we see a clear pattern: UV verbs with $-i$ go with recipient undergoer constructions [recipient UVVERB $-i$ theme] as in (24) and -ké with theme undergoer constructions [theme UV-VERB-ké recipient] as in (25). In the homeland group, all cases of UV constructions are recipient undergoer with suffix -i; and all are uttered by the same speaker. Despite the limited number of instances, they follow the same pattern as the heritage group.

Recipient undergoer

$\mathrm{R}$

(24) Tyah

$\mathrm{T}$

child male Uv-show-APPL book

'The boy is being shown a book.' (JVN-20150911-NiSa-clips)

Theme undergoer

(25) Tas
$\mathrm{T}$

tas-DEF UV-give-APPL person male-DEF again

'The bag is being given to the man again.' (JVN-20150826-MaSo-clips)

In other words, the morphology in undergoer voice constructions in both heritage and homeland speakers follows the same pattern: verbs with $-i$ go with recipient undergoers and verbs with -ké go with theme undergoers. The only difference is one utterance in which a heritage speaker uses suffix $-i$ with a theme undergoer. This is congruent with the general preference for and tendency to overgeneralize suffix $-i$ in the group of heritage speakers.

To sum up, in all the constructions used to express transfer events (PO, DO, argument omission and undergoer voice), heritage speakers of Javanese have a clear preference for verbs ending with the applicative suffix $-i$. In contrast, homeland speakers of Javanese show a more diverse use of the applicative suffixes, reflecting a preference for -ké in PO and argument omission constructions, and a preference for $-i$ in DO and UV constructions. Heritage speakers appear to have overgeneralized suffix $-i$ to all contexts.

\subsubsection{Discussion}

In the preceding paragraph, we saw that heritage speakers of Javanese diverge from the homeland speakers in two ways: (i) they show different frequencies of transfer event constructions, and (ii) they show different uses of applicative suffixes. We will now discuss these two developments in turn. 
Concerning the frequency of transfer constructions, we observed three main differences: (1) DO constructions are used significantly more by heritage speakers, (2) two-predicate constructions are used significantly more by heritage speakers (3) undergoer constructions are also used significantly more by heritage speakers.

The increase in the use of DO constructions as well as two-predicate constructions among Javanese heritage speakers in Suriname is congruent with our expectations that cross-linguistic influence would cause Surinamese Javanese to converge to Sranantongo. Further evidence that Surinamese Javanese has converged toward Sranantongo comes from the order of the arguments in the DO construction: heritage speakers prefer the recipient-theme order, which is the only possible order found in Sranantongo. The fact that this is also the only possible order in Dutch may reinforce this trend. Another factor possibly influencing the preference for recipient-theme order over the theme-recipient order is that the former is unmarked. Recipient-theme order is crosslinguistically the most common order in DO constructions, and it is the order that children acquire first (Yip and Matthews, 2007: 14). Since the sample of these specific constructions was very small, this analysis remains qualitative here and is in need of further data.

DO and two-predicate constructions are the most frequent types of constructions in Sranantongo (section 3.2). It can be assumed that heritage speakers of Javanese in Suriname, who are also fluent in Sranantongo, transfer these preferences when speaking their heritage language. This type of indirect transfer is made possible by the fact that Javanese and Sranantongo both allow DO and two-predicate constructions. As predicted by the 'Alternation Hypothesis' (Jansen et al., 1981; Moro, 2016), heritage speakers tend to extend the frequency of the constructions that are shared by both languages, a form of "frequential copying" (Johanson 2002: 292). Note that, since nothing new is really "transferred' into the heritage language, this change should be referred to as a socalled 'system-preserving' change, in which the system (type of constructions) remains the same, but the frequency of the constructions varies (for an overview of system-preserving frequency changes in heritage languages, see Moro, 2016: 13-16). Interestingly, the increase of two-predicate constructions in heritage Javanese is directly opposite to the effect shown in heritage Ambon Malay (Moro and Klamer, 2015), where the use of the two-predicate construction actually decreases because of influence from Dutch. This further supports our claim that Sranantongo exerts the strongest influence on Javanese in Suriname, because of the length and intensity of the contact. Furthermore, it shows that the two-predicate construction is very vulnerable to cross-linguistic 
influence, and may increase (as in Suriname) or decrease (as in The Netherlands), depending on the structures present in the contact languages.

Overall, Surinamese Javanese appears to have converged toward Sranantongo rather than toward Dutch, at least in the domain of transfer events discussed here. Although the increase in the use of DO construction may (partially) be related to Dutch influence (as Dutch also allows DO constructions), the increase in the use of two-predicate constructions clearly points to Sranantongo influence. Even if nowadays, the two-predicate construction with $\mathrm{V}_{2} g i$ is in some cases reanalyzed as a PO, this is a recent development and it can be assumed that in the Sranantongo spoken during the early times of language contact, two-predicate construction were still common. Furthermore, the interlingual identification of Sranantongo gi 'give' with Javanese kèk 'give' reinforces this construction in Javanese. In formulating our hypothesis in section 4.1, we predicted that the influence of Sranantongo on heritage Javanese would be relatively stronger than that of Dutch. This prediction was borne out, thereby showing that length and intensity of contact are an important factor in the outcome of language contact.

An unpredicted and remarkable difference between the heritage and homeland group is the surprisingly high proportion of undergoer voice constructions in the heritage group (Table 5). This pattern might be explained by the fact that Javanese, as many Austronesian languages, is a so-called "patientprominent" language (e.g. Gil, 2002; Goudswaard, 2005). Properties of "patientprominence" include a high overall frequency of undergoer voice constructions and an early acquisition of undergoer voice constructions by children (Gil, 2002: 275). For example, in the acquisition of Jakartan Indonesian, children acquire the undergoer voice $\mathrm{di}^{-}$- prefix earlier than the actor voice $\mathrm{N}$ prefix. This is explained by two factors: the formal simplicity of $d i$-in meaning as well as function, ${ }^{21}$ and its high frequency in adult input (Gil, 2008: 222). An additional explaining factor may be that the usage of $d i$ - involves no morphophonology, in contrast to the actor voice $N$ - prefix, which requires assimilation to the stem.

The fact that the undergoer voice prefix is overused by heritage speakers in this study may thus be due to the specific language acquisition path they underwent. Since heritage speakers shift to the dominant language(s) before the

21 Gil (2002: 213) argues that in contrast to "passives in English and other similar languages", "prefix di- is a weak voice marker, associated with a relatively simple semantic function, namely asserting the existence of a patient argument". 
acquisition of the heritage language has completed its course, as adults they still rely on strategies that are otherwise typically found among (homeland) children (Benmamoun et al., 2013: 151). One of these strategies is using the undergoer voice prefix, since this prefix has been mastered early on in acquisition. Another possible factor favoring the use of this prefix may be its saliency: the prefix is phonologically salient (in contrast to the nasal prefix, which assimilates to the initial consonant of the stem) and has a transparent meaning. It could also be the case that heritage speakers perceive the di-prefix as a clear distinguishing feature of Javanese in contrast to the other language, and use it to emphasize this difference, as a sort of identity marker. This idea seems to be confirmed in a study by Villerius (2018b) on the use of voice in Surinamese Javanese. It was found that Surinamese heritage speakers use the undergoer voice with the same frequency as homeland Indonesian speakers, but that older heritage speakers use it more frequently than younger speakers, which could confirm this use as an 'identity marker'. This hypothesis would need further investigation, but in any case, 'Patient-prominence' appears to be a basic and robust feature of Javanese, and has become even more prominent in the heritage variety.

Next to these differences in structure, the heritage group also differs from the homeland group in their use of bound morphology. The heritage group uses the suffix $-i$ on transfer verbs regardless of whether it introduces a recipient or theme argument, whereas the homeland group follows the expected tendency that sees -ké introducing the theme argument, and - $i$ introducing the recipient argument. As mentioned in section 4.3.2, the use of -ké and $-i$ with theme and recipient arguments is just a tendency, and considerable variability is found among monolinguals. As predicted by the 'Vulnerability Hypothesis' (de Prada Pérez, 2015), the variability found in the homeland language may be the locus of language-internal mechanisms leading to simplification, i.e. a reduction of the number of forms and subsequent semantic overgeneralization of one form. We define language-internal here as cases where there is no direct cross-linguistic transfer from the contact language into the heritage language, even if the contact situation does provide the pressure to cause this change. Heritage speakers overgeneralize this variability in favor of the suffix $-i$, as this suffix is associated with a wider range of meanings than -ké and is thus more easily generalizable (see section 3.1.1). The overgeneralization of $-i$ may be indicative of a reanalysis of this applicative suffix by heritage speakers, as a general argument-introducing suffix in $\mathrm{PO}$ and argument omission constructions. We propose that this overgeneralization may be explained by the Vulnerability Hypothesis: since there is already some variability in the homeland grammar (the two suffixes do not map to different structures one-to-one, but more as a 
general tendency), heritage speakers will have more difficulty keeping these two suffixes apart, and therefore overgeneralize one of them.

\section{$5 \quad$ Summary and Conclusion}

This study has shown that there are differences in the expression of the ditransitive events between heritage Surinamese Javanese and homeland Indonesian Javanese speakers. On the one hand, heritage speakers have changed the frequency of possible constructions under cross-linguistic influence, and on the other hand, heritage speakers are overgeneralizing applicative suffix $-i$, a language-internal development reinforced by contact. The fact that Sranantongo exerts a stronger influence on Javanese heritage speakers than Dutch does shows that duration and intensity of contact are an important factor in the outcome of language contact. Direct cross-linguistic transfer can lead to changes in frequency patterns, whereas language-internal developments reinforced by contact can lead to changes in how multilingual heritage speakers use morphology.

The data analysed in this study were limited in two ways: we only considered verbs of physical and mental transfer, and animacy and discourse accessibility were kept constant. Animacy has been shown to play a role in the use of the dative alternation in for instance English and Dutch (Bresnan et al., 2007), and variation on this condition might have given a more detailed result. Another limitation was that we used only elicited data, which possibly yields different results than naturalistic data, since the elicitation might be considered to be more of a 'formal' situation. For example, it has been shown that for Dutch, there is some variability in the use of the dative alternation between written and spoken language (Colleman and Bernolet, 2012). Further research should focus on the exact role of animacy, involving a wider range of ditransitive constructions, with the inclusion of naturalistic data. Ideally, it would combine elicited data with naturalistic data.

Another issue that requires further study is the different influence from Dutch and Sranantongo on Surinamese Javanese: in this study this difference has been inferred from the language history only, but a follow-up study should ideally take into consideration the amount of code-switches and the domains of use of the two languages in daily life. Another option would be to do a priming study, to see which of the languages shows the strongest priming effect, as has been done for example for Papiamento (Kootstra and Şahin, 2015).

This study has shown that multilingualism and language contact may have effects on multiple linguistic levels at the same time. A long period of contact 
with Sranantongo has structurally influenced the expression of transfer events in Surinamese Javanese. In addition, Surinamese Javanese speakers overgeneralize one of the two applicative suffixes found in transfer constructions, a phenomenon that results from simplification processes.

\section{Acknowledgements}

Earlier versions of this paper have been presented at De Grote Taaldag 2016 and APLL 8 (2016). We thank Pieter Muysken, Suzanne Aalberse, Robert Borges and two anonymous reviewers for their insightful comments on previous versions of this paper. The research by Sophie Villerius on Surinamese Javanese was funded by a grant from the graduate program of the Netherlands Graduate School of Linguistics (LOT), who received the funds from the Netherlands Organisation for Scientific Research in the context of the project "Language - from cognition to communication" (Nwo project number 022-004-015). Francesca Moro and Marian Klamer acknowledge support from the VICI research project 'Reconstructing the past through languages of the present: the Lesser Sunda Islands' at Leiden University, funded by the Netherlands Organisation for Scientific Research (Nwo project number 27770-012).

\section{Abbreviations}

$\begin{array}{ll}\mathrm{APPL} & =\text { applicative } \\ \mathrm{ART} & =\text { article } \\ \mathrm{AV} & =\text { actor voice } \\ \mathrm{DEF} & =\text { definite } \\ \mathrm{DO} & =\text { double object } \\ \mathrm{EXIST} & =\text { existential verb } \\ \mathrm{INDF} & =\text { indefinite } \\ \text { LOC } & =\text { locative } \\ \text { PAST } & =\text { past tense } \\ \text { PO } & =\text { prepositional object } \\ \text { POSS } & =\text { possessive } \\ \text { PRES } & =\text { present tense } \\ \mathrm{R} & =\text { recipient argument } \\ \mathrm{RDP} & =\text { reduplication } \\ \mathrm{REL} & =\text { relative pronoun } \\ \text { SG } & =\text { singular }\end{array}$


$\mathrm{T}=$ theme argument

UV $=$ undergoer voice.

\section{References}

Adamson, Lilian and Cefas Van Rossem. 1994. Creole literature. In Jacques Arends, Pieter Muysken and Norval Smith (eds.), Pidgins and Creoles: An introduction, 75-84. Amsterdam: John Benjamins.

Adamson, Lilian and Norval Smith. 1994. Sranan. In Jacques Arends, Pieter Muysken and Norval Smith (eds.), Pidgins and Creoles: An introduction, 219-232. Amsterdam: John Benjamins.

Aikhenvald, Alexandra Y. and R.M.W. Dixon (eds.). 2006. Grammars in contact: a crosslinguistic typology. Oxford/New York: Oxford University Press.

Arends, Jacques. 1989. Syntactic developments in Sranan: Creolization as a gradual process. Doctoral dissertation, University of Nijmegen.

Arps, Ben, Els Bogaerts, Willem van der Molen, Ignatius Surpriyanto, and Jan van den Veerdonk (in collaboration with Betty Litamahuputty). 2000. Hedendaags Javaans. Semaian 2o. Leiden: Leiden University, Opleiding Talen en Culturen van Zuid-Oost Azië en Oceanië.

Benmamoun, Elabbas, Silvina Montrul, and Maria Polinsky. 2013. Heritage languages and their speakers: Opportunities and challenges for linguistics. Theoretical Linguistics 39: 129-181.

Boumans, Louis. 2006. The attributive possessive in Moroccan Arabic spoken by young bilinguals in the Netherlands and their peers in Morocco. Bilingualism: Language and Cognition 9(3): 213-231.

Bresnan, Joan, Anna Cueni, Tatiana Nikitina, and R. Harald Baayen. 2007. Predicting the dative alternation. In Gerlof Bouma, Irene Krämer, and Joost Zwarts (eds.), Cognitive foundations of interpretation, 69-94. Amsterdam: KNAW.

Broekhuis, Hans, Norbert Corver, and Riet Vos. 2015. Syntax of Dutch. Verbs and Verb Phrases: Vol. 1. Amsterdam: Amsterdam University Press.

Bruyn, Adrienne, Pieter Muysken, and Maaike Verrips. 1999. Double-Object Constructions in the Creole Languages: Development and Acquisition. In Michel DeGraff (ed.), Language creation and language change: Creolization, diachrony, and development, 329-374. Cambridge, MA: The MIT Press.

Charry, Eddy, Geert Koefoed and Pieter Muysken (eds.). 1983. De talen van Suriname. Muiderberg: Dick Coutinho.

Colleman, Timothy. 2009. Verb disposition in argument structure alternations: a corpus study of the dative alternation in Dutch. Language Sciences 31: 593-611.

Colleman, Timothy and Sarah Bernolet. 2012. Alternation biases in corpora vs. picture description experiments: DO-biased and PD-biased verbs in the Dutch dative 
alternation. In Dagmar Divjak and Stefan Th. Gries (eds.), Frequency effects in language representation, 87-125. Berlin: De Gruyter Mouton.

Conners, Thomas J. 2008. Tengger Javanese. New Haven, CT: Yale University dissertation.

Crowley, Terry. 2002. Serial verbs in Oceanic. A descriptive typology. New York/Oxford: Oxford University Press.

Davies, William D. 2010. A Grammar of Madurese. Berlin: De Gruyter Mouton.

Derveld, F.E.R. 1982. Hoe dachten de planters en overige bevolkingsgroepen over de Javanen? Oso 1(2): 23-43.

Deusen-Scholl, Nelleke Van. 2003. Toward a definition of heritage language: sociopolitical and pedagogical considerations. Journal of Language, Identity \& Education 2(3). 211-230. doi:10.1207/S15327701JLIE0203.

Ewing, Michael C. 2005. Grammar and Inference in Conversation: Identifying clause structure in spoken Javanese. Amsterdam: John Benjamins.

Gil, David. 2002. The prefixes di- and N- in Malay/Indonesian dialects. In Fay Wouk and Malcolm Ross (eds.), The history and typology of western Austronesian voice systems, 241-283. Canberra: Pacific Linguistics.

Gil, David. 2008. The acquisition of voice morphology in Jakarta Indonesian. In Natalia Gagarina and Insa Gulzow (eds.), The acquisition of verbs and their grammar: The effect of particular languages, 201-227. Springer Netherlands.

Goudswaard, Nelleke. 2005. The Begak (Ida'an) Language of Sabah. Utrecht: LOT Publications.

Haspelmath, Martin. 2013. Ditransitive constructions: the verb 'give'. In Dryer, Matthew S. and Martin Haspelmath (eds.), The World Atlas of Language Structures Online. Leipzig: Max Planck Institute for Evolutionary Anthropology. (Available online at http://wals.info/chapter/105, Accessed on 2017-04-11.)

Hemmings, Charlotte. 2013. Causatives and Applicatives: the case for polysemy in Javanese. soAs Working Papers in Linguistics 16: 167-194.

Hoefte, Rosemarijn. 1987. Het politiek bewustzijn van Hindostaanse en Javaanse contractarbeiders, 1910-1940. Oso 6(1). 25-34.

Irizarri van Suchtelen, Pablo. 2016. Spanish as a heritage language in the Netherlands. Utrecht: LOT Publications.

Jansen, Bert, Josien Lalleman and Pieter Muysken. 1981. The alternation hypothesis: acquisition of Dutch word order by Turkish and Moroccan foreign workers. Language Learning, 31(2): 315-336.

Johanson, Lars. 2002. Contact-induced change in a code-copying framework. In Mari C. Jones and Edith Esch (eds.), Language change: the interplay of internal, external and extra-linguistic factors, 285-314. Berlin: Mouton de Gruyter.

Kleine, Christa Mary de. 2007. 1999. A morphosyntactic analysis of Surinamese Dutch as spoken by the creole population of Paramaribo Suriname. New York: City University of New York dissertation. 
Montrul, Silvina and Melissa Bowles. 2009. Back to basics: Incomplete knowledge of differential object marking in Spanish heritage speakers. Bilingualism: Language and Cognition $12(3): 363-383$.

Moro, Francesca and Marian Klamer. 2015. Give-constructions in Heritage Ambon Malay in The Netherlands. Journal of Language Contact 8(2): 263-298.

Moro, Francesca. 2016. Dynamics of Ambon Malay: Comparing Ambon and the Netherlands. Utrecht: LOT Publications.

Muysken, Pieter. 2017. The transformation of a colonial language: Surinamese Dutch. In Kofi Yakpo and Pieter C. Muysken (eds.), Boundaries and Bridges: Multilingual ecologies in the Guianas, 283-310. Berlin: De Gruyter Mouton.

Nationaal Archief. 1999. Javaanse immigranten in Suriname. http://www.gahetna.nl/ collectie/index/ntoo346.

Ogloblin, Alexander K. 2005. Javanese. In Alexander Adelaar and Nikolaus P. Himmelmann (eds.), The Austronesian languages of Asia and Madagascar. London: Routledge.

Onar Valk, Pelin and Ad Backus. 2013. Syntactic change in an immigrant language: from non-finite to finite subordinate clauses in Turkish. Keeleteaduse, Eesti ja soome-ugri Linguistics, ajakiri. Journal of Estonian and Finno-Ugric 4(2): 7-29.

Prada Pérez, Ana de. 2015. Spanish-Catalan bilingual subject pronoun production and the Vulnerability Hypothesis. Paper presented at the Bilingualism in the Hispanic and Lusophone World Conference, Leiden University, The Netherlands. Retrieved on March 30, 2017 from http://media.leidenuniv.nl/legacy/booklet-final-14-01-2015 .pdf.

Polinsky, Maria. 2008. Gender under incomplete acquisition: Heritage speakers' knowledge of noun categorization. Heritage Language Journal 6(1): 40-71.

Poplack, Shana and Stephen Levey. 2010. Contact-induced grammatical change: A cautionary tale. In Peter Auer and Jürgen Erich Schmidt (eds.), Language and Space. An International Handbook of Linguistic Variation: Theories and Methods, 391-419. Berlin: De Gruyter Mouton.

Robson, Stuart. 1992. Javanese grammarfor students. Clayton, Victoria: Centre of Southeast Asian Studies, Monash University.

Robson, Stuart and Singgih Wibisono. 2002. Javanese English Dictionary. Hong Kong: Periplus Editions.

Kootstra, Gerrit Jan and Hülya Şahin. 2015. Cross-linguistic structural priming as a mechanism of language change: Evidence from Papiamento-Dutch bilinguals in Aruba and the Netherlands. In Hülya Şahin, Cross-linguistic influences: Dutch in contact with Papiamento and Turkish. Utrecht: LOT Publications.

Sato, Yosuke. 2008. Minimalist Interfaces: Selected Issues in Indonesian and Javanese. Doctoral dissertation, University of Arizona, Tucson.

Sebba, Mark. 1987. The Syntax of Serial Verbs: An Investigation Into Serialisation in Sranan and Other Languages. Amsterdam: John Benjamins. 
Silva-Corvalán, Carmen. 1994. Language Contact and Change: Spanish in Los Angeles. Oxford: Clarendon Press.

Silva-Corvalán, Carmen. 2008. The limits of convergence in language contact. Journal of Language Contact 2(1): 213-224.

Sneddon, James Neil, Alexander Adelaar, Dwi Noverini Djenar and Michael C. Ewing. 2010. Indonesian reference grammar. Crows Nest, NSw: Allen \& Unwin.

Sorace, Antonella, Ludovica Serratrice, Francesca Filiaci, and Michela Baldo. 2009. Discourse conditions on subject pronoun realization: Testing the linguistic intuitions of older bilingual children. Lingua 119(3): 46o-477.

Thomason, Sarah G. and Terrence Kaufman. 1991. Language contact, creolization, and genetic linguistics. Berkeley: University of California Press.

Villerius, Sophie. 2017. Developments in Surinamese Javanese. In Kofi Yakpo and Pieter C. Muysken (eds.), Boundaries and Bridges: Multilingual ecologies in the Guianas, 151-178. Berlin: De Gruyter Mouton.

Villerius, Sophie. 2018a. Development of Surinamese Javanese: Language contact and change in a multilingual context. Utrecht: LOT Publications.

Villerius, Sophie. 2018b. Voice and information structure in Surinamese Javanese. Linguistics in The Netherlands 35(1): 139-153.

Voorhoeve, Jan. 1964. Sranan Syntax. Language. Vol. 40. Amsterdam: North-Holland Publishing Company.

Vruggink, Hein. 2001. Surinaams-Javaans-Nederlands Woordenboek. Leiden: KITLV Press.

Winford, Donald and Ingo Plag. 2013. Sranan structure dataset. In Michaelis, Susanne Maria, Philippe Maurer, Martin Haspelmath, and Magnus Huber (eds.), Atlas of Pidgin and Creole Language Structures Online. Leipzig: Max Planck Institute for Evolutionary Anthropology. (Available online at http://apics-online.info/contributions/2, Accessed on 2017-06-08.)

Yakpo, Kofi. 2015. Code-switching and social change: Convergent language mixing in a multilingual society. In Gerard Stell and Kofi Yakpo (eds.), Code-switching Between Structural and Sociolinguistic Perspectives, 259-288. Berlin: De Gruyter.

Yakpo, Kofi. 2017. Creole in transition: Contact with Dutch and typological change in Sranan. In Kofi Yakpo and Pieter C. Muysken (eds.), Boundaries and Bridges: Multilingual ecologies in the Guianas, 57-86. Berlin: De Gruyter Mouton.

Yakpo, Kofi and Pieter Muysken. 2014. Language change in a multiple contact setting: The case of Sarnami (Suriname). In Isabelle Buchstaller, Anders Holmberg and Mohammad Almoaily (eds.), Pidgins and Creoles beyond Africa-Europe Encounters, 101-140. Amsterdam: John Benjamins.

Yip, Virginia and Steven Matthews. 2007. The bilingual child: Early development and language contact. Cambridge: Cambridge University Press. 